\title{
Decentralisation and Development: Can Uganda Now Pass the Test of Being a Role Model?
}

\author{
David K.W. Ssonko \\ School of Civil Service and Governance \\ Uganda Management Institute \\ Email: dssonko@yahoo.co.ug
}

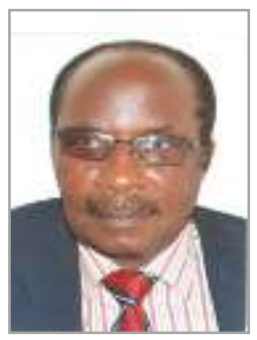

\begin{abstract}
Uganda's Government of the National Resistance Movement (NRM) assumed power in 1986, in an environment of political turmoil, and initiated a policy of decentralisation as a way of restoring state credibility and deepening democracy. Decentralisation was accordingly legislated under the Local Government Act of 1997, as a framework act directing the decentralisation process. The aim of the Act was to enable implementation of decentralisation provisions provided for under Chapter 11 of the 1995 National Constitution.
\end{abstract}

The decentralisation policy in Uganda aimed at improving local democracy, effectiveness, efficiency and sustainability in the delivery of essential services country-wide. Improved service delivery was in turn expected to make significant positive impact on people's quality of life. Unfortunately, the implementation of decentralisation appears to have concentrated more on administrative objectives as a means of promoting popular democracy and less on service delivery which would have led to economic transformation and better lives for the majority of Ugandans, and now new districts are being created without corresponding improvements in service delivery. Surprisingly, this is happening in the midst of external praise that decentralisation reform in Uganda is one of the most far-reaching local government reform programmes in the developing world.

The paper explores the role of decentralisation in development and how it can be undermined by political factors. It highlights the development of decentralisation in Uganda, discusses its achievements, failure and challenges, and concludes that the decentralisation programme which was ambitious and politically driven has had mixed results in terms of enhancing service delivery and should be seriously reviewed and strengthened if it is to remain as a role model in Africa.

Key Words: Decentralisation, development, democratisation and service delivery

\section{Introduction}

Since the 1980s governments in sub-Saharan Africa have been undergoing economic and institutional reform. Among the many institutional reforms, decentralisation has been instituted to advance political democratisation and to promote socio-economic development (Saito, 2002). Local governance is promoted as a structural arrangement through which local people and communities, with support from other national, regional and international actors can participate in the fight against poverty at close range (Kauzya, 2003). 
Kauzya (2005) argues that decentralisation is part of efforts to promote people's participation in decision making processes and development activities which in turn promotes good governance. This is based on the premise that decentralised governance provides a structural arrangement and a level playing field for stakeholders to promote peace, democracy and development.

Under the decentralisation policy, service delivery institutions and their governance are decentralised in order to improve access to services particularly for the rural poor (Bashaasha et al, 2011). Decentralisation therefore transfers administrative and political powers from central to regional or sub-national governments.

Decentralisation of local governance is one of the most ambitious reforms undertaken by Uganda since independence in 1962 (Saxena et al, 2010). Various scholars have praised the Ugandan decentralisation reform initiated in 1992 as exceptional among developing countries, in terms of the scale and scope of the transfer of power and responsibilities to the local level (Steiner, 2006). They have referred to the decentralisation programme as 'one of the most far-reaching local government reform programme in the developing world' (Francis and James, 2003) and as 'one of the most radical devolution initiatives of any country at this time' (Mitchinson, 2003). Such praise obviously makes Uganda's decentralisation programme a model for other countries to emulate.

This paper illustrates the role of decentralisation in development and highlights the development of decentralisation in Uganda, including its achievements, failure and challenges.

The paper concludes that the ambitious and politically-driven decentralisation in Uganda has had mixed results in terms of enhancing service delivery and recommends that for Uganda to remain a model, the decentralisation programme must be seriously reviewed and strengthened with a view to promoting efficient services delivery.

\section{The decentralisation structure in Uganda}

Uganda's decentralisation process dates backs to 1987 when the present National Resistance Movement (NRM) government took power through an armed civil war which was waged on the basis of popular civil strengths. The first step by the (NRM) government in the decentralisation process was the enactment of the 1987 Resistance Council Committee's Statute which legalised Resistance Councils (RCs) and gave them powers in their local areas of jurisdiction (Bashaasha, 2011).

The current decentralisation reform was officially launched in 1992 through a presidential policy statement (Steiner, 2006). It was first enshrined in the Local Government (Resistance Councils) Statute 1993 and later in the 1995 Constitution and the Local Governments Act 1997.

As outlined in Figure 1, the local government systems is formed by a five-tiered structure of local councils (LC) which consists of the Village (LC1), Parish (LC2), Sub-county (LC3), Country (LC4) 
and District (LC5); Ward or Parish (LC2), Municipality (LC4) and the City (LC5) in urban areas. The District and the City are the highest local government levels, while the Sub-county, Town and City Division are referred to as lower local government levels.

Figure 1: Uganda's five-tier local government administrative system
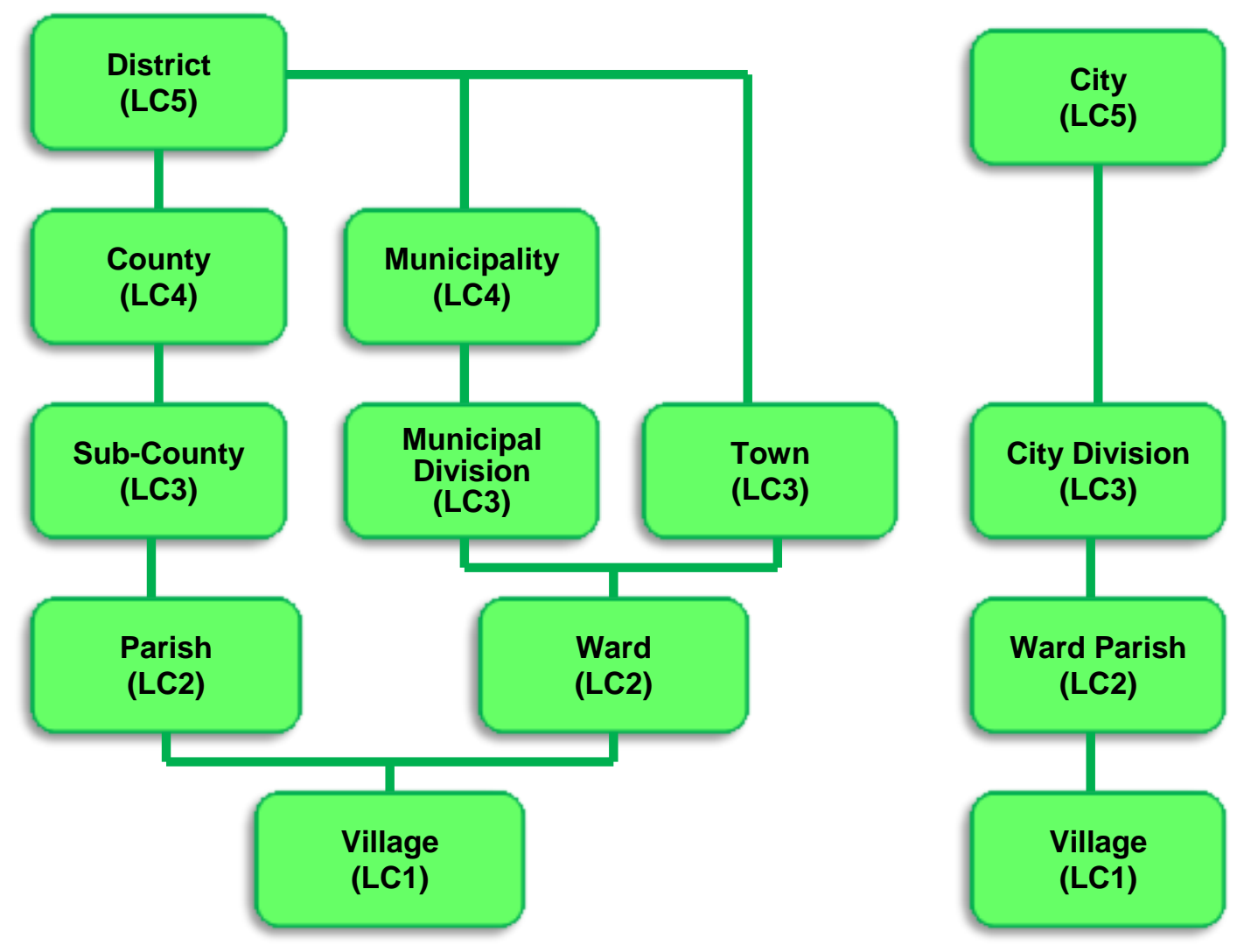

Source: Steiner (2006)

The 1995 Constitution and Local Governments Act 1997 provided for the District to be a unit of decentralisation and spelt out the functions devolved to local governments, and the relevant funding mechanisms. The idea was to involve the people in the way they are governed, in decision making, identifying problems, setting priorities, planning implementation and monitoring, to ensure better utilisation of resources both financial and human, and value for money through participation, transparency and accountability and sensitisation.

The District Local Council (DLC) and the Sub-County Council are established as corporate legal entities under the Local Governments Act 1997. These councils are vested with powers to:

(i) enact local laws necessary for the effective governance of the areas within their jurisdiction;

(ii) ensure accountability and transparency in conducting council business and using council funds;

(iii) ensure effective planning / budgeting to spur development and delivery of public services, and

(iv) monitor the delivery of public service on priority national programmes (Natamba et.al 2010). 
Devolution in Uganda has therefore been a gradual process with functions being transferred from the centre to local bodies. Central government retained responsibility for national security, planning, immigration, foreign affairs and national projects, and all other functions were devolved to local institutions (Satane et al,2010). According to the Local Governments Act 1997 (ss. 96-99) the role of the centre vis-a-vis line ministries and the Ministry of Local Government (MoLG) is limited to coordination, advocacy for local government, inspection, monitoring, technical advice and training supervision within respective sectors.

\section{Perceived merits of decentralisation}

'Decentralisation' refers to the transfer of power over decision-making and implementation to lower administrative levels for purposes of improving efficiency and effectiveness (Kiyaga-Nsubuga, 2004). Several scholars (Muriisa, 2008; Okidi and Guloba, 2006; Obenga-Odom, 2010) have discussed different ways in which decentralisation can be implemented. These include:

- deconcentration, whereby powers and responsibilities over defined functions are transferred to lower administrative units that are tightly controlled from the centre;

- delegation, by which lower units may be granted some relative discretion in managing defined responsibilities, while still reporting to the centre;

- devolution, when the lower levels are given substantial control over decision-making and implementation, with the centre largely restricted to policy setting, monitoring and supervision.

In the case of devolution the division of powers and responsibilities is defined in a legal framework, and the units to which power has been devolved are subjected to control by local beneficiaries. Uganda has experienced decentralisation both as a system and process of devolution of power from the central to the local authorities (Okidi and Gulaba, 2006).

Although the motives of decentralisation differ across countries (Bashaasha et al,2011; Naido, 2002) the major argument supporting decentralisation in developing countries includes economic and political gains. Naido (2002) states the economic justification for decentralisation as being allocated and productive efficiency aimed at improving public service delivery. Allocative efficiency involves better matching of public services to local preferences, whereas productive efficiency involves increased accountability, fewer levels of bureaucracy, and better knowledge of local costs. The political justification relates to considerations of local participation, good governance, and democratisation.

Ekipo (2007) and the World Bank (2000) provide a clear and detailed outline of the perceived merits of decentralisation which include; 
- facilitating good governance by empowering the local population to participate in matters affecting their lives. This allows for the local people to be watchdogs and ensure that public officials deliver quality goods and services.

- improving service delivery: it is argued that the lower tiers of government can deliver services such as water, education, sanitation, and health effectively. At the lower levels of government, politicians and public servants are more aware of the needs of their community, and aware of the preferences of local populations.

- productive efficiency: this refers to the contention that local governments can produce goods and services at lower cost than central governments, and costs of producing goods and services will be minimised. The usual 'middle-man syndrome' and bureaucracy involving contract procedures is reduced.

- improving the efficiency of central government: decentralisation allows central governments to concentrate on national and international issues, eg: macroeconomic policies for the entire economy, rather than being pre-occupied with service delivery.

- cost recovery: decentralisation may make it less difficult for government to recover the costs of public services, as services will be more demand-responsive hence increasing the household willingness to pay for services that match their demand.

- fostering competition may result in better public goods at lower prices. Competition allows for a bundles of local public goods to be produced and individuals can reveal their preferences for those goods by exercising some form of 'exit' option at the extreme, moving to jurisdictions that satisfy their tastes (Azfar-et.al.2005).

The NRM government went for decentralisation largely to deliver better services to communities. The Local Governments Act, 1997, places responsibility for delivery of most services with local governments. The objective of the Act was:

(i) to give full effect to the decentralisation of functions, powers, responsibilities and services at all levels of local government;

(ii) to insure democratic participation in, and control of decision making by the people concerned;

(iii) to establish a democratic, political and gender sensitive, administrative set-up in local governments;

(iv) to establish sources of revenue and financial accountability, and

(v) to provide for elections of local councils (see sec.2 of the Act).

The latter objective was in line with the national objectives and directive principles enshrined in the 1995 Constitution which provides that;

The state shall be guided by the principle of decentralisation and devolution of government functions and powers to the people at appropriate levels where they can best manage and direct their own affairs. 
Part 2 of the second schedule of the Local Government Act, 1997 gives power to local governments (Local governments) to provide education services, medical and health services; undertake maintenance and provision of water supplies; construction, maintenance and rehabilitation of roads; budget for recurrent and development expenditures as well as collect local revenue.

Decentralisation policy was therefore aimed at improving local democracy, effectiveness, efficiency and sustainability in the delivery of essential services country wide (Klaver, 2009). According to the Ministry of Local Government (MoLG) (2006), the objectives of Uganda's decentralisation are to:

- transfer real power to Local governments and reduce the workload of remote, underresourced central officials

- $\quad$ hring political and administrative control over services at the point of delivery in order to improve accountability and efficiency.

- free local managers from central constraints allow them to develop organisational structures tailored to local circumstances.

- improve financial accountability by establishing a clear link between payment of taxes and provision of services.

- $\quad$ improve local council capabilities to plan, finance and manage service delivery to their constituents, which was a total reversal of the centralizing tendencies of earlier governments.

- $\quad$ promote local economic development (MoLG Module A, 2003; Klaver, 2009). Hence as observed by Bashaasha et.al (2011) decentralisation in Uganda is based on three interlinked aspects; (i) political and legislative empowerment of the people, (ii) fiscal devolution, and (iii) control of the administrative machinery by the local councils.

The transfer of authority for planning, and administration and financial management was central to Uganda's decentralisation process (Okidi and Guloba, 2006), and central government line ministries should only be responsible for issuing regulations, policies and advice, benchmarking standards, and providing supervisory and inspectorate services to local governments.

In order to empower local governments to fulfill their responsibilities, they are entitled to levy, charge, and collect local taxes and fees and to receive intergovernmental grants. According to the Local Governments Act 1997, local governments are entitled to unconditional grants, conditional grants and equalisation grants. Unconditional grants are intended to fund decentralisation functions as shown by the Act, while the conditional grants are supposed to fund national priority programme areas. The equalisation grants are supposed to be given to local governments lagging behind the national standard of service delivery. Furthermore with regard to taxes and fees, district and urban local governments are allowed to impose property tax, several forms of non-tax revenue (market dues, trading licenses, parking fees, education contributions etc, and until fiscal year 2005/06 graduated personal tax). 


\section{Ingredients of successful decentralisation}

Decentralisation is often hailed because it brings government closer to its citizens and provides opportunities for participation in decision- making. Achieving this goal, however, depends on a variety of conditions (Wong and Scott, 2007) which Ekpo (2007) has referred to as ingredients for successful decentralisation. Before analysing current trends of decentralisation in Uganda, it is important to appreciate those conditions or ingredients as follows:

- full commitment from national and sub-national government and adequate resources. Central government must be willing to give control and recognise the importance of subnational government in service delivery;

- $\quad$ an appropriate legislative framework which clearly defines responsibilities and powers of sub-national governments, and the expected relationship between central and lower levels of government;

accountability and transparency: decentralisation must be accompanied by checks and balances so that there is no abuse of power, as one way of fighting corruption and clientelism;

- adequate financial and staff resources to support effective decentralisation. Sub-national governments must have the legal authority to raise revenue to support expenditure requirements. The fiscal relationship between the centre and lower tiers of government must be clearly defined on the basis of equity, fairness and justice.

- $\quad$ capacity at sub-national government level: xub-national government must have sufficient professional and well-trained staff. Capacity denotes the ability, competency, efficiency of sub-national governments to plan, implement, manage and evaluate relevant policies, strategies or programs for their jurisdictions.

This paper will later explore the level at which the above ingredients necessary for the proper implementation of decentralisation exist in Uganda. If there are gaps within the ingredients then decentralisation and service delivery at lower levels of government may remain problematic which may debar Uganda from being seen as a 'super-implementer' of devolved decentralisation.

\section{Decentralisation landmarks}

The decentralisation agenda in Uganda has been implemented with an emphasis on institutional arrangement and capacity building. So far, several achievements have been registered with varying degree of success across different districts (Bitarabeho, 2003; Okidi and Guloba, 2006; Bashaasha, 2011). As observed by Ministry of Local Government (2006), institutionally Uganda has made significant progress in the implementation of decentralisation. First, the legal framework is well defined in the Constitution and operationalised by the Local Governments Act of 1997; secondpolitical decentralisation has led to regular local elections and limited devolved decisionmaking, and third reasonable progress has been made to implement fiscal decentralisation, with $38 \%$ 
of the national budget being spent through both conditional and non-conditional grants to local government (Klaver, 2009).

According to Emorut (2006) decentralisation has empowered the citizens, heighted their awareness of the different custodians of responsibilities, delivered coordinated services, promoted creative local resource mobilisation, and increased the responsiveness of public investment to popular demands. Okidi and Guloba (2006) argue that the administrative hierarchy in the decentralisation system of governance has promoted the development of channels of communication between the population and local and central government leaders. Okidi and Guloba(ibid) suggest that through the local council system, local-level political powers (as outlined above) have enabled citizens to elect local leaders who have come under increasing performance and accountability demands from electorates.

Although a lot needs to be done, service delivery has improved under decentralisation, particularly with respect to the infrastructure for primary education and health care. In 1997, decentralisation coincided with the introduction of Universal Primary Education (UPE) policy, which provided for free primary education for all school-age children, first limited to four children per family, but then extended to all children in 2003 (Bashaasha et al 2011). The UPE policy aimed to expand access, enhance equity and increase efficiency in education. Although the non-completion rate of children in UPE schools is now as high as $75 \%$ for reasons such as forced early marriages, or family poverty leading to child labour (New Vision, 9 April 2010), the policy has enabled some poor children in rural areas to access education. Nevertheless, the quality of education in UPE schools still requires improvement if the majority of the rural poor are to benefit.

Health infrastructure has also improved under decentralisation. When user fees for government health facilities were abolished in 2001 (except for private facilities in hospitals), the health system was reorganised into a hierarchy that mirrors government structures (Okidi and Gulaba, 2006). The system now comprises national and regional referral hospitals, and Health Centres categorised as level IV, III, II, or I depending on the range of services offered at a given facility level. The operationalisation of this structure required the construction of several new facilities leading to growth in the number of health facilities, especially at Health Centre II level. The staffing and medicine stocks at these facilities remains challenge and citizens voice concern as to whether health service provision is a priority for the Ugandan Government.

\section{The challenges}

With limited examples of successful service delivery in Uganda resulting from decentralisation, the country still faces a number of major challenges in deepening and institutionalising decentralisation. Unless these challenges are addressed, Uganda risks losing its previously status as achieving one of the most far-reaching decentralisations in the developing world. These challenges include: limited 
funding; inadequate human resources (HR); limited political autonomy and interference by central ministries; frequent creation of new districts; gaps in service delivery; corruption and conflicts. These challenges are now discussed in more detail.

\section{Limited funding}

One of the most critical challenges faced by local governments in Uganda is limited finance due to limited sources of local tax revenue and overdependence on grants from central government. This challenge as noted by Bashaasha et al (2011) is of major importance because any shortfall in financial resources leads either to non-delivery of services or delivery of sub-standard services and products.

Traditionally, the main local revenue sources in Uganda have been graduated tax, property tax, business licences, and market dues. Graduated tax contributed over $80 \%$ of local revenue for rural local governments and about $30 \%$ for urban authorities (MoLG, 2006). Unfortunately, this source was scrapped for political reasons in 2005 as a campaign measure in preparation of the 2006 elections, which reduced the autonomy of local governments. Furthermore, local revenues have been declining and the amount of locally raised revenue as a percentage of total local government funding has fallen each financial year. In some local governments, local revenue accounts for only $3 \%$ of the total budget (MoLG, 2006). A critical analysis of local government budgets reveals their dependence on central government, which makes the districts agents of the central government rather than independent local governments as envisaged under Article 176 of the Uganda Constitution, suggesting that Uganda is be promoting deconcentration rather than decentralisation.

On average, about $80 \%$ of the central transfers are conditional - ie: earmarked by the centre for the provision of specific services leaving local governments little power determines local priorities. The remaining 20\% of transfers are composed of unconditional and equalisation grants (Entisham et al, 2006). In practice the unconditional transfers are mostly used to cover administrative costs, including council salaries and allowances, rather than for service delivery.

To worsen the situation, conditional and unconditional grants from the central government have continued to decline. For example, in 2011/2012 the unconditional grant for all local governments decreased from USh 156,944 billion (US\$63m) to USh 151,155 billion (US\$60.5m) (National Budget 2011/2012). Declining revenues and the failure to use unconditional transfers on service provision have weakened the accountability of local authorities to service beneficiaries, and threaten the autonomous functioning of local governments.

\section{Inadequate HR capacities}

In addition to the shortage of financial resources, local governments also suffer from a shortage of skilled and experienced manpower for both technical staff and politicians (Steiner, 2006). As Onyach-Olaa (2007) has revealed, local governments in Uganda continue to operate at minimal 
staffing levels, in some instances as low as 9\% of the approved establishment. Furthermore, staffing problems are exacerbated by a shortage of equipment and materials. A study by Azfar et al (2000) found that only $17 \%$ of health facility respondents reported that all their employees had the necessary equipment and resources to do their work. In remote districts such as Abim, Kalangala, Kabong, Buvuma, and Bukwa there are difficulties in recruiting and retaining professional staff such as health workers, engineers, planners, or teachers. A further constraint is the fact that some local governments through the politically-oriented District Service Commissions (DSC) appoint staff, on the basis of ethnicity or residence rather than merit, which has adverse effects on the quality of service provision (Steiner, 2006).

Politically, the quality of councilors is affected by their level of education. At the moment, there is no minimum education requirement for anyone to hold office as a district councilor, and academic qualifications are not part of the eligibility requirements for the office. There is widespread consensus that councilors with very low levels of education fail to express themselves during plenary sessions, while some cannot make written contributions (Natamba et.al 2010). Such low levels of education undermines effective debates among councilors with their educated technical staff, and some local politicians, have an inferiority complex which has sometimes led to conflicts with technical staff.

\section{Limited political autonomy and central interference}

Legally and politically, the Local Government Council is responsible for all local government functions, including planning, financial accountability and the delivery of public goods and services (Natamba et al 2010). In reality, however, local government political leadership holds no controlling authority to direct how funds allocated to the district are utilised. The Chief Administrative Officer (CAO) who is the district's accounting officer is appointed by central government and reports directly to the Ministry of Local Government.

Previously, under Article 188 of the Uganda Constitution, the CAO was appointed by the District Service Commission (DSC) which arrangement provided reasonable political control to councilors over CAOs. However, in 2005 in the same Constitution (Amendment) Act, No.11 that removed presidential term limit, the Uganda Government recentralised the role of the CAO, transferring powers of appointment from the DSC to the Public Service Commission based in Kampala. While the government claimed that this change was necessary to remove corrupt CAOs, Green (2008) has correctly noted that the control of central government transfers to local governments by central government appointees 'cuts at the very heart of the decentralised reform'. In addition, each district has a Resident District Commissioner (RDC) who is appointed by the President, and such RDCs have always supported the NRM party which has been in power since 1986. Thus the creation of the RDC office seems to be an attempt to weaken the District Chairperson, who under Article 183 of the Constitution is elected by universal adult suffrage as the political head of the district. More 
disturbingly, some of the RDC's roles conflict with those of the elected Chairperson, as both are, responsible for coordination and monitoring of district services provision. In districts where the District Chairpersons belong to the opposition there have been conflicts with RDCs which negatively affects the district's development.

Similarly, in November 2010 the Ugandan Parliament at the request of the Cabinet passed the Kampala Capital City Authority (KCCA) Act which brought the affairs of the Kampala under direct supervision of the central government. Previously, Kampala City Council was administered as a district under the Local Government Act 1997. According to the KCCA Act, the Town Clerk who was formally the highest financial officer in the City was replaced by an Executive Director answerable to the Minister for Kampala Capital City Authority. The elected Mayor became the Lord Mayor, a largely ceremonial position. In essence Kampala's administration was recentralised.

So despite central government's claim of commitment to decentralisation, line ministries have retained substantial power over local policy making (Steiner, 2006). Both the Uganda Constitution of 1995 and the Local Government Act, 1997, defining the range of services and functions for each level of government under decentralisation, with local governments responsible for implementation/delivery of basic services including primary health, primary education, water and sanitation, feeder roads, agriculture production, planning etc. Yet, the decentralisation programming has left significant functions supervised by central line ministries in policy development, capacity development and quality assurance.

In practice the roles of different levels of government in service delivery have not been very clearly distinguished which has at times caused policy conflict. Almost all the line ministries have maintained an active hand in service delivery, policy formulation and guidance. For example the Ministry of Education and Sports (MOES) has appointed engineering assistants in the districts, who certify works as a condition for payment for infrastructure built by local governments e.g. through the School Facilitation Grant (SFG). Similarly, the Ministry of Works and Transport has set up sub-national Technical Support Units or regional workshops which are heavily involved in implementation, which weakens the role the local governments.

\section{Creation of new districts}

Uganda has seen an explosion in the number of districts (Green, 2008) which increased from 33 in 1986 to 80 in 2007, and 112 in 2012, and, in June 2012, Cabinet approved the creation of another 25 districts to make a total of 137 ! While ostensibly been guided by the 1995 Constitution this expansion, whose Article 179 permits the government to create new districts 'on the necessity for effective administration and the need to bring services closer to the people', it is more likely that the NRM 
government has used the creation of new districts as a source of patronage in order to continue winning elections which undermines decentralisation benefits.

The increased number of local governments has put immense pressure on service delivery and the capacity to manage new administrations (Klaver et al 2009). This has resulted in a decline in the number of local government authorities meeting performance-assessment criteria (minimum conditions) from $80 \%$ in 2006 to $34 \%$ in 2008 (MoLG, 2009). The creation of new local governments is seen by the central government as being in tune with the original objectives of decentralisation, but unfortunately service delivery in both new and old districts has declined due to lack of financial and human capacity, as resourcing has not been increased. As observed by Okidi and Guloba (2006), by creating so many political districts, Uganda runs the risk of excessive decentralisation, which could contribute to lowering local-level economic growth.

The creation of 25 new districts makes little economic or financial sense, especially as several new districts have failed to raise more than $5 \%$ of their total revenue from internal sources. Instead, these new districts have become a political bargaining chip that the NRM government uses to reward cadres and lure opponents by offering them political jobs that do note enhance service delivery. It would possibly make sense to reduce the number of districts and form larger provincial administrative units provide greater political oversight, cut administrative costs and allow for unified planning over a larger jurisdiction.

\section{Gaps in service delivery}

While the general objectives of decentralisation were to respond to local needs, existing data show no improvement in social services or quality of life for local communities (Jeppsson and Okuonzi, 2000). In fact, many indicators have either remained the same or worsened. For example, a large proportion of Uganda's population still lives below the poverty line, with $25 \%$ living in absolute poverty (UBOS 2011). Yet improvements in the health sector were expected to deliver better access to health services, better quality of health care and, ultimately, a decline in the rate of illness and death (Bashasha et al 2011). As many people cannot afford private medical services, the government of Uganda decentralised free health services to districts and to health sub-districts (health centres). However a recent study by ACODE (2010), found numerous problems facing health care provision in the health centres, including poor funding of healthcare services, in erratic drug distribution, and minimal transparency in the use of drugs and medicines; chronic shortage of trained health workers especially at lower tier health centres; lack of appropriate medical equipment; and that funds intended for health facilities were used for administrative costs. Consequently, healthcare services remains out of reach of the in the rural areas and decentralisation has not led to improved services. 
In education, since the inception of the Universal Primary Education (UPE) programme in 1997, enrolment rose from 5.3million children in 1996 to 7.6 million in 2003 (MoES, 2005), but without a corresponding increase in infrastructure or staffing. Children in the final classes of UPE often find problems in reading and writing which reflects the poor quality of education in the UPE schools, which are the majority of schools in many districts. Therefore, enhancing the output and quality of education in schools, especially those that serve the poor, is essential for the promotion of pro-poor growth in Uganda, and a critical part of multi-dimensional poverty reduction.

\section{Corruption}

In spite of Uganda initial success in decentralisation, widely heralded by the international community, corruption remains widespread at all levels of society and the country faces major challenges (Transparency International, 2009). The survey report of the Inspectorate of Government (2009) noted that corruption - in the form of bribery, financial leakages, conflict of interest, embezzlement, false accounting, fraud, influence peddling, and nepotism, theft of public funds or theft of public assets - remains at impediment to development and barrier to poverty reduction in Uganda at national and local government levels. Public confidence in government officials (politicians and technocrats) is severely undermined by regular corruption scandals. A majority of citizens surveyed in 2005 by a regional research firm, Afro Barometer, perceived corruption to be rampant. In addition, 36\% of respondents to the survey believed that most or all government officials, at central or local level, were involved in corruption. In fact it is sometimes believed that decentralisation in Uganda has led to a dispersion of corruption, 'redefining the character of corruption relationships from those controlled by the centre to those controlled by district - level officials' (Steiner, 2006). For example during the financial year 2009/10 the Office of the Auditor General (2011) conducted a Value for Money Audit on seven districts of Apac, Arua, Bundibugyo, Bushenyi, Kamuli, Moroto and Mukono focusing on procurement of goods and services during 2007/08, 2008/09 and 2009/10, which revealed numerous corruption problems.

There is no doubt therefore that corruption of public officials in Uganda exacts a tremendous economic and social toll on societies. It raises the cost of government and encourages wasteful, inefficient projects; it increases cynicism towards politics; it undermines democratic processes and civil society's it diverts scarce resources from worthy projects; it discourages legitimate investors while attracting dishonest con artist; and increases economic hardships and fiscal difficulties. One of the greatest threats of corruption is a loss of faith in government institutions undermining decentralisation objectives. 


\section{Conclusions}

Indeed, if the Uganda decentralisation project was implemented and functioned provided for in the existing legal infrastructure, it should offer much potential for an impact efficient service delivery through popular participation and responsive policy. Unfortunately despite the exceptional reform efforts, a gulf remains between principles and practice. This paper has identified a number of challenges to the implementation of the decentralisation reform, which give reason for concerns about whether Uganda can still claim to be a role model for decentralisation. The assessment in this paper suggests that Uganda has at best implemented only partial decentralisation, and at worst appears to have paid lip service to it.

Both the Uganda Constitution of 1995 and the Local Governments Act, 1997 provided the legal framework and authority to the policy of decentralisation. The aims were to transfer real power to local governments; to bring political and administrative control over services closer to people; to free local managers from central government constraints; to improve financial accountability and responsibility by establishing a clear link between taxation services provision; and to improve the capacity of local councils to plan, finance, and manage services delivery. However, decentralisation of finances to local governments continues to be a major challenge in the implementation of decentralisation in Uganda. Local governments are still unable to mobilise adequate local financial resources more than 15 years after they were formed, and those resources have further been constrained by the politically influenced policy decision to remove the graduated tax which previously constituted the lion's share of the locally generated revenues. Strengthening local finances should be a core objective of any decentralisation strategy, and it is imperative for central government to continue the process of transferring sufficient financial resources to local governments, and for local governments to utilise these honestly (without corruption) in areas of greatest priority in their jurisdictions. Capacity building in human resources also remains a challenge to Uganda's decentralisation.

Central government must desist from the temptation of manipulating the decentralisation process to suit their patronage interests. The rampant creation of the new districts which are not self-sustaining provides good evidence for such manipulation. Disempowering the District Service Commissions from appointing the Chief Administrative Officers is another form of manipulation.

The Uganda Government now needs to refocus true decentralisation so as to promote national development and improved quality of life for the majority of Ugandans. At presently, rural Uganda suffers serious inadequacies in infrastructure, social services, and living conditions of the people, while economic productivity is low. More than $85 \%$ of Ugandans live in rural areas, and the majority of those below the poverty line are the rural poor. A properly constituted and committed decentralised system would benefit such people. Similarly, local governments must strive to eradicate poverty from 
their jurisdictions, as poverty eradication is fundamental to human development, lays the foundation for overall development of society. Short of that Uganda's once praised decentralisation reform will continue to bring diluted results.

\section{References}

ACODE (2010) The tragedy of Uganda's health System: The case of Paminya Health Centre. Info sheet No.9, 2010.

Auditor General (2011) Second Annual Report on corruption trends in Uganda, Kampala.

Azfa O. et.al (2005) Decentralisation, governance and public service: The impact of institutional arrangements". In Mwanga et.al eds: Devolution and Development, Asgate.

Azfar O et al (2000) Making decentralisation work: An empirical investigation of governance and public services in Uganda. IRIS Centre, University of Maryland.

Bashaasha B, Mangheni M.N and Nkonya E (2011) Decentralisation and rural services delivery in Uganda. IFPRI Discussion Paper 01063.

Bitarabeho J (2003) Curbing corruption and promoting transparency in local governments: The experience of Bushenyi district. A paper presented at World Bank Institute, Washington DC.

Ekpo A.H. (2007) Decentralisation and Services Delivery; Framework, AERC, Nairobi, Kenya.

Emorut S (2006) Decentralisation and good governance: Innovation approaches to public service management and service delivery. Memoir, MoLG, Kampala. Uganda.

Francis P and James R (2003) Balancing rural Poverty reduction and citizen participation: The contradictions of Uganda's decentralisation programme. World Development 31(2), pp.325-337.

Green E.D. (2008) Decentralisation and conflict in Uganda. Conflict, Security and Development, Vol.8, No.4, pp 427-450.

Inspectorate of Government (2009) The state of corruption in Uganda, Kampala.

Jeppsson, and Okuonzi A (2000) Vertical or holistic decentralisation of the health sector? Experiences from Zambia and Uganda. International Journal of Health Planning and Management, Vol. 15, pp273-289.

Kauzya J.M (2003) Local government capacity building for full range participation: concepts, frameworks and experiences in African countries. ST/ESA/2003/DP 33 DESA Discussion Paper No. 3, United Nations.

Kauzya J.M (2005) Decentralisation: Prospects for peace, democracy and development. DPADM Discussion Paper.

Kiyaga- Nsubuga J (2004) Decentralisation, Local governance and poverty reduction: A theoretical exploration. A paper presented at Uganda Management Institute, Kampala, Uganda.

Klaver D et al (2009) "Harmonisation, decentralisation and local governance: Enhancing aid effectiveness. Workshop Report.

Ministry of Local Government (2006) Decentralisation Policy Strategy Framework, Kampala, Uganda.

Muriisa R.B (2008) Decentralisation in Uganda: Prospects for improved Service Delivery. African Development, Vol.XXXIII, No.4

Naido J.P (2002) Education decentralisation in sub-Saharan Africa. A paper presented at the $46^{\text {th }}$ conference of the comparative and International Education Society in Orlando.

Natamba E.F. Muyomba- Tamale L et.al (2010) Local government councils performance in Uganda. ACODE Policy Research Paper series No. 39.

New Vision- Uganda’s leading Daily, 2010 “Uganda has the highest drop-out rate”. 9 April 2010.

Obeng- Odoom F (2010) Is decentralisation in Ghana Pro-poor? Commonwealth Journal of Local Governance, Issue 6 pp.120-126.

Okidi J. A. and Guloba M. (2006) Decentralisation and development: Emerging issues from Uganda's experience, EPRC, Occasional Paper No.31. 
Onyach- Olaa (2007) The success and challenges of decentralisation in Uganda. A paper presented at a Rural Development Workshop, Kampala Uganda.

Saito F. (2002) Decentralisation for participatory development in Uganda: Limitations and prospects. Ryukoku University.

Saxena K, Sohini P. and Goel P.R (2010) Decentralisation in Uganda. National Council of Applied Economic Research ((NCAER).

Steiner S (2006) Decentralisation in Uganda: Exploring the constraints for poverty reduction. GIGA working Paper No.31.

Steiner, S (2008) Constraints of the implementation of decentralisation implications for poverty. In Crownford and Hartmann(ed) Decentralisation in Africa, pp.33-72

Transparency International (2009) Overviews of corruption in Uganda.www.U4.no.

World Bank (2000) World Bank Development Report 2001. Washington, DC. 